\title{
JUDICIAL DIALOGUE IN THE LIGHT OF PROTOCOL NO. 16 TO THE EUROPEAN CONVENTION ON HUMAN RIGHTS
}

\author{
Dr. sc. Bruna Žuber* \\ Špela Lovšin **
}

\author{
UDK: $341.231 .14(4)$ \\ https://doi.org/10.30925/zpfsr.40.2.10 \\ Ur.: 31. prosinca 2018. \\ Pr.: 11. veljače 2019. \\ Pregledni znanstveni rad
}

\begin{abstract}
Summary
The authors discuss legal nature of the Protocol No. 16 to the European Convention on Human Rights (ECHR) which entered into force on 1 August 2018. With the aim of improving the judicial dialogue between European Court of Human Rights (ECtHR) and highest national courts, the Protocol No. 16 introduced the advisory opinion procedure at the ECtHR level. A detailed analysis of the impact of advisory opinion procedure on the judicial dialogue is included and is further supported by the reviews of cases at the ECtHR against Slovenia, Belgium and Italy, which illustrate how a possibility to request an advisory opinion could have prevented finding of a human right's violation on the Strasbourg level and raised the effectiveness of human rights standards. The authors believe the Protocol No. 16 has brought a lot of potential for improvement of the judicial dialogue, which could lead to better understanding of ECHR standards, as interpreted by the ECtHR, and therefore prevent human rights violations already on a national level.
\end{abstract}

Keywords: judicial dialogue; Protocol No. 16 to the European Convention on Human Rights; advisory opinion; European Court of Human Rights.

\section{INTRODUCTION}

Protocol No. 16 to the European Convention on Human Rights (hereinafter referred as the Protocol No. 16), which entered into force for the Parties concerned on 1 August 2018, enables the highest courts and tribunals of a State Party to ask the European Court on Human Rights (hereinafter referred as ECtHR) for advisory opinions on questions of principle relating to the interpretation or application of the rights and freedoms defined in the European Convention on Human Rights (hereinafter

* Bruna Žuber, Ph.D., teaching assistant, University of Ljubljana, Faculty of Law and senior judicial advisor at the Supreme Court of the Republic of Slovenia, bruna.zuber@pf.uni-lj.si.

** Špela Lovšin, first cycle graduate in law, Master's student, University of Ljubljana, Faculty of Law, spelalovsin@gmail.com. 
referred as ECHR) or the Protocols thereto.

The scientific problem of this article is the efficiency and effectiveness analysis of new means and approaches for conducting judicial dialogue and thus for preventing violations of human rights and freedoms, on the basis of Protocol No. 16. The aim of this paper is to provide scientific analysis of the effects of the advisory opinion procedure on the judicial dialogue between the national courts and the ECtHR. To conduct the research successfully, the authors used the following methods of scientific knowledge: logical (analysis, synthesis, induction, deduction), historical, systemic and formally dogmatic.

To achieve the goal, the authors first analyse the genesis of Protocol No. 16 and its substance. They further discuss the role of the advisory opinions for national court proceedings and its possible impacts on the judicial dialogue realisation in European countries through theory and case law.

In the second part of the paper, the authors discuss the intended effects of advisory opinions in the case of judicial decision-making in some European states. The authors' hypothesis is that the advisory opinion procedure under Protocol No. 16 will have a significant impact on a judicial dialogue between the ECtHR and the highest states national courts. The hypothesis is tested on the example of past ECtHR's cases against Slovenia, Belgium and Italy. On the foundations of Protocol No. 16, the authors examine whether the finding of a violation in certain cases could have been prevented and whether the dialogue between national courts and the ECtHR could have been enhanced if national courts had requested an advisory opinion before adopting a decision. All the foregoing illustrates the originality of this scientific paper.

Although the authors at some points critically evaluate the current state of play in the area of judicial dialogue among the national courts and the ECtHR they encouragingly conclude that adopting Protocol No. 16 could enrich judicial dialogue between the national courts and the ECtHR and thus consolidate the understanding of the human rights' and fundamental freedoms' protection in the whole Europe.

\section{PROTOCOL NO. 16 TO THE ECHR AND ITS NOVELTIES}

\subsection{Reasons for adoption of Protocol No. 16.}

The adoption of Protocol No. 16 was part of an ongoing series of reforms of the Strasbourg human rights protection system ${ }^{1}$ and it has been open for signature by the State Parties to the ECHR since 2 October 2013. By legal nature, it is an optional protocol, producing effects solely with respect to those Member States ${ }^{2}$ that will have proceeded to its ratification and after ten ratifications are completed. To date, the tenth

1 More on this see: Schabas, W. A., The European Convention on Human Rights: A Commentary, Oxford, Oxford University Press, 2015, pp. 26-32; Harris, D., et al., Law of the European Convention on Human Rights, Oxford, Oxford University Press, 2018, pp. 174-179.

2 The term »Member States « is used in this article to designate State Parties to the ECHR and is hereinafter referred to as »States«, while the term »State Parties« is used to denote States which have ratified the Protocol No. 16. 
ratification recently took place, ${ }^{3}$ by France on 12 April 2018, and according to its Article 8 the Protocol No. 16 entered into force for the states concerned on 1 August $2018 .^{4}$

The idea of the reforms, initiated over a decade ago, arose mainly from the ECtHR's overload and, in consequence, the lengthened average time of application processing as well as the significant number of applications concerning systemic violations. ${ }^{5}$ It follows from this that there is not only a practical but also a substantial aim to the Protocol No. 16 i.e. to reduce the large backlog of applications, and to intensify and strengthen the dialogue between higher national courts and the ECtHR. ${ }^{6}$ The substantial aim has been also highlighted in the Protocol's Preamble, which states that 'the extension of the Court's competence to give advisory opinions will further enhance the interaction between the ECtHR and national authorities and thereby reinforce implementation of the ECHR, in accordance with the principle of subsidiarity'. This principle was clearly reflected in the Interlaken Declaration of 19 February 2010, in which the Conference pointed out that it is first and foremost the responsibility of the States to guarantee the implementation of the Convention rights. ${ }^{7}$ Having regard to the ECtHR's current workload, a reinforcement of the national courts' role in applying the ECHR is of the utmost importance and all tools working towards that end should be seriously examined. ${ }^{8}$

Although the implementation of the advisory opinion procedure seems to be prima facie a great solution as it will presumably reduce the burden of ECtHR's caseload on the one hand and help domestic courts to develop and protect human rights standards on a national level on the other hand, it was cautioned in the legal theory by some scholars that the advisory opinion procedure does not entail an actual decrease of the ECtHR's caseload but only the distribution of ECtHR's activities into two separate competences: the advisory opinion and the application procedure. ${ }^{9}$

3 The following High Contracting Parties to the ECHR have ratified the Protocol No. 16 (by the 8 December 2018): Albania, Armenia, Estonia, Finland, France, Georgia, Lithuania, San Marino, Slovenia and Ukraine.

4 Council of Europe, France ratifies Protocol No. 16 to the European Convention on Human Rights, triggering its entry into force, <https:/www.coe.int/en/web/tbilisi/-/france-ratifiesprotocol-no-16-to-the-european-convention-on-human-rights-triggering-its-entry-into-force> $12^{\text {th }}$ of April 2018, $8^{\text {th }}$ of December 2018.

5 Paprocka, A., Ziółkowski, M., Advisory opinions under Protocol No. 16 to the European Convention on Human Rights, Cambridge, European Constitutional Law Review, vol. 11, 2/2015, p. 275.

6 Đorđević, S., Protocol 16 to the European Convention on Human Rights and Freedoms, Niš, Law and Politics, vol. 12, 2/2014, p. 109.

7 Interlaken Declaration, adopted at the High Level Conference on the Future of the European Court of Human Rights organized within the framework of the Swiss Chairmanship of the Committee of Ministers of the Council of Europe in Interlaken, Switzerland, on $18^{\text {th }}-19^{\text {th }}$ February 2010, PP 6 and part B., paras. 4 and 9 of the Action Plan.

8 European Court on Human Rights, Reflection Paper on the proposal to extend the Court's advisory jurisdiction, Strasbourg, 2013, para. 9.

9 See Đorđević, S., op. cit., p. 107. 


\subsection{The substance of Protocol No. 16}

In line with Article 1(1) of the Protocol No. 16, highest courts and tribunals of State Parties may request the ECtHR to give advisory opinions. By stating that relevant courts or tribunals "may" request the ECtHR to give an advisory opinion, it is clear that it is only optional and not obligatory for them to do so. Each State Party is obliged to specify which highest courts or tribunals may request an advisory opinion of the ECtHR and may change their choice at any time. ${ }^{10}$ Still, it is important to stress out that, according to the Protocol No. 16, a national body must fulfill three conditions in order to quality as entitled to request an opinion: (1) the body must constitute a court or tribunal in the meaning of the ECHR, ${ }^{11}$ (2) legal norms establishing the given body's position in the structure of national bodies of power have to put it on the top of the hierarchical structure of competence in the given legal system, and (3) in a proceeding before this body, questions of principle relating to the interpretation or application of the rights and freedoms defined in the ECHR need to be raised. ${ }^{12}$ Interestingly, Protocol No. 16 does not indicate whether there is any control by the ECtHR over the choice made by a State Party, which could hypothetically lead to a situation in which a State might designate a body that is not one of its 'highest courts or tribunals ${ }^{13}$ It is not yet clear whether the ECtHR could decline to issue an opinion in such situations. We believe that the ECtHR could take such a request into a consideration with the aim to provide effective protection of the ECHR's rights and freedoms already on a national level. On the other hand, however, it could be argued that consideration of such request could go beyond the linguistic interpretation of the Protocol No. 16 and that State Parties could easily abuse such an extended interpretation, which could lead to overburdening of the ECtHR with the requests for the advisory opinions.

Procedural requirements that have to be met by the requesting national body are set in Article 1(3) of the Protocol No. 16 and reflect the aim of the procedure, which is not to transfer the dispute to the ECtHR, but rather to give the requesting court or tribunal guidance on ECHR issues when determining the case before it. ${ }^{14}$

10 See Article 1(1) and Article 10 of the Protocol No. 16.

11 The terms 'court' and 'tribunal' are subjected to an autonomous interpretation by the ECtHR. According to its well-established case law, a court or tribunal is characterised in the substantive sense of the term by its judicial function, that is to say determining matters within its competence on the basis of rules of law and after proceedings conducted in a prescribed manner. See, for example Sramek v. Austria, no. 8790/79, 22 October 1984, para. 36, and Cyprus v. Turkey [GC], no. 25781/94, 10 May 2001, para. 233.

12 Paprocka, A., Ziółkowski, M., op. cit., p. 279.

13 Schabas, W. A., op. cit., p. 1215.

14 These requirements firstly imply that the requesting court or tribunal must have reflected upon the necessity and utility of requesting an advisory opinion of the ECtHR, and secondly, they imply that the requesting court or tribunal is in a position to set out the relevant legal and factual background, thereby allowing the ECtHR to focus on the question(s) of principle relating to the interpretation or application of the ECHR or the Protocols thereto. More on this see: Council of Europe, Explanatory Report: Protocol No. 16 to the Convention for the Protection of Human Rights and Fundamental Freedoms, Strasbourg, 2013, para. 11. 
One of the most important aspects of the request for the advisory opinion in this regard is also the nature of the questions on which a domestic court or tribunal may request the advisory opinion. ${ }^{15}$ In its request, which should be in the context of a case pending before the requesting court or tribunal, a national body can raise any question of principle relating to the interpretation or application of the provisions containing rights and freedoms defined in the ECHR or the Protocols thereto. ${ }^{16}$ This is, without a doubt, a somewhat vague provision, which will have to be interpreted with the help of ECtHR's case law. Most importantly, it is not clear with what level of precision should the domestic courts convince the Grand Chamber that the specific request concerns a question of principle. Due to the interest of the ECtHR to raise the level of protection of the Convention rights and freedoms on the national level and to provide a uniformity of respect for these standards among all Member States of the Council of Europe, it is expected that the threshold for arguing the existence of the question of principle by a requesting court will not be disproportionate and that the decision on taking the request into consideration will be subjected to a high level of discretion of the deciding panel of the Grand Chamber. With such selectivity, ECtHR could avoid deciding on questions, which are at the moment still too delicate to be decided upon, in order to avoid the denunciation by certain States and the risk of its authority to be undermined. Yet, it is also possible to speculate that due to the interest of reducing the ECtHR's workload, the threshold will be set high, forcing the requesting courts to form greatly convincing arguments, unless they want their requests to be dismissed already on the doorstep to the ECtHR. Still, based on past experience it seems more likely the Grand Chamber not to set unreasonably high threshold.

Advisory opinions shall not be binding. ${ }^{17}$ Since the opinions take place in the context of the judicial dialogue between the ECtHR and domestic courts and tribunals, ${ }^{18}$ it is implicit that it is on the requesting court to decide on the effects of the advisory opinion in the domestic proceedings. At the moment, it is difficult to predict the frequency of the State Parties to make use of the advisory opinion proceeding and to assess what effects will they delegate to the advisory opinions on the national level. It cannot be ruled out that the State Parties will transfer the provisions of the Protocol No. 16 directly into their national legislation and thus try to even more approximate

15 Article 1(2). Requests for in abstracto review of legistalitons are excluded. For more on this see Council of Europe, Explanatory Report: Protocol No. 16 to the Convention for the Protection of Human Rights and Fundamental Freedoms, Strasbourg, 2013, para. 10.

16 It can be concluded from this provision that advisory opinions cannot settle questions referring to procedural and institutional issues regulated by the ECHR and its Protocols; see also Paprocka, A., Ziółkowski, M., op. cit., p. 285.

17 See Article 5 of the Protocol No. 16

18 More on the judicial dialogue between the ECtHR and domestic courts see: Ribičič, C., Ustavno sodišče - ESČP - Sodišče EU, Ljubljana, Podjetje in delo, vol. 36, 6-7/2001, pp. 1054-1061; Rinceanu, J., Judicial dialogue between the European Court of Human Rights and national supreme courts, in: Spinellis, C., et al. (eds.), Europe in Crisis: Crime, Criminal Justice, and the Way Forward. Essays in honour of Nestor Courakis. Vol. II: Essays in English, German, French, and Italian, Athens, Ant. N. Sakkoulas Publishers L.P., 2017, pp. 1029-1041; Gerards, J., Fleuren, J., Implementation of the ECHR and the case-law of the European Court of Human Rights in national case-law: A comparative analysis, Antwerp, Intersentia, 2014. 
the appliance of this legal institute to highest national courts and tribunals. ${ }^{19}$ Also, given the fact that advisory opinions are to be delivered by the Grand Chamber, we should expect them to have considerable jurisprudential weight in the ECtHR's future decision-making. ${ }^{20}$

With regard to the non-binding nature of the advisory opinions, it needs to be stressed out that the delivery of an advisory opinion on a question arising in the context of a case pending before a national court or tribunal does not undermine the right to an individual application to the ECtHR where the domestic court did not follow the non-binding opinion. ${ }^{21}$ Therefore, if the domestic court does not act in line with an advisory opinion, there is a risk of subsequent duplication of proceedings before the ECtHR, in case the party dissatisfied, which would make it harder to achieve one of the aims of the Protocol - to reduce ECtHR's caseload. ${ }^{22}$

\section{ADVISORY OPINIONS AND JUDICIAL DIALOGUE}

\subsection{Impacts of advisory opinions on the judicial dialogue realisation}

Until this day no advisory opinion has been issued and it is therefore only possible to speculate about the effects of these proceedings, since it will probably take some time before State Parties will fully comprehend the importance of this instrument and finally request the issuance of the advisory opinion by the ECtHR. Nevertheless, even when the ECtHR will finally receive an opportunity to address a "question of principle", many initial legal difficulties would probably await to be resolved before the beginning of the sole decision-making process. ${ }^{23}$

It is possible to predict that the advisory opinion procedure will provide a broader scope of implementation of the ECHR rights and freedoms as interpreted by the ECtHR, mainly because when the highest national courts or tribunals will doubt whether rights and freedoms guaranteed by the ECHR in the proceedings in front of them are threatened, they will be free to clarify that at the very source. ${ }^{24}$ Furthermore,

19 For example, the Republic of Slovenia has implemented the provisions of the Article 267 of the Treaty on the Functioning of the European Union regarding preliminary ruling procedure at the European Court of Justice into its national legislation through Article 113.a of the Courts Act (Official Gazette of the Republic of Slovenia no. 94/07, 45/08, 96/09, 86/10, 33/11, 75/12, $63 / 13,17 / 15,23 / 17$ and 22/18). Legislative initiative of this kind cannot be excluded in Member States also in regard to the advisory opinions procedure.

20 Mowbray, A., European Court of Human Rights: May 2013-April 2014, Hull, European Public Law, vol. 20, 4/2014, p. 583.

21 European Court on Human Rights, Reflection Paper on the proposal to extend the Court's advisory jurisdiction, Strasbourg, 2013, paras. 45-46.

22 See: Đorđević, S., op. cit., p. 106.

23 Such difficulties would be, for example, the question of what are "the national highest courts or tribunals", what is a "question of principle" that needs to be raised in the request and also, what happens with the request if a similar question has already been raised and addressed in another case at the ECtHR.

24 Jóźwicki, W., Protocol 16 to the ECHR: A Convenient Tool for Judicial Dialogue and Better Domestic Implementation of the Convention?, in: Kużelewska, E., et al. (eds.), European Judicial Systems as a Challenge for Democracy, European Integration and Democracy Series, 
by clarifying the law at a stage of uncertainty, the advisory opinions will channel the judicial discourse on legal concepts from the beginning and will assist the highest domestic courts to apply the ECHR standards and to avoid future violations..$^{25}$ Also, since the highest domestic courts will have to take a stand on the advisory opinions in their final judgments, the general awareness of ECHR standards amongst lower domestic courts will also be raised. ${ }^{26}$

Even though the advisory opinions under the Protocol No. 16 will not be binding, they will be issued by the Grand Chamber, which could lead to the emergence of more general implementation obligations on the side of the State Parties, as they should also take into consideration verdicts in cases to which they were not parties and undertake general means aimed at implementing to their own legal systems the ECHR rights and freedoms as interpreted in the ECtHR's case law. ${ }^{27}$ It is speculated in the legal theory that the non-binding character of the advisory opinions may with time become inviting to the Grand Chamber to formulate perhaps more far reaching arguments than it would in its ordinary proceedings. ${ }^{28}$ The assertion of the ECtHR's constitutional function will further add to its role as external control organ for the domestic authorities' human rights abidance and would therefore bolster the legitimacy of international human rights protection. ${ }^{29}$

The advisory opinions could have a beneficial effect on the resources of the ECtHR, since they will prevent a violation before its occurrence on the national level and therefore reduce the number of potential individual applications. Also, the development of the ECHR's uniform interpretation standards will contribute to alleged violations of the ECHR's rights and freedoms being adequately addressed already at the national level, which could lead to the reduction of the ECtHR's caseload.

\subsection{Effects of ECHR's advisory opinions and CJEU's preliminary ruling procedure in the light of judicial dialogue}

\subsubsection{Brief comparison between advisory opinions and preliminary ruling procedure}

One of the most important tools for establishing and maintaining the judicial dialogue on the European level is also a preliminary ruling procedure conducted by the Court of Justice of the European Union (hereinafter referred to as CJEU) under the Article 267 of the Treaty on the Functioning of the European Union ${ }^{30}$ (hereinafter referred to as TFEU). This procedure has been subjected to many discussions in the legal theory, ${ }^{31}$ which is why we further limit ourselves only to describing the most

Antwerp, Intersentia, 2015, p. 192.

Jahn, J., op. cit., p. 828.

26 ibid., p. 829.

27 Jóźwicki, W., op. cit., pp. 193-194.

28 ibid., p. 195.

29 Jahn, J., op. cit., p. 841.

30 Consolidated version of the Treaty on the Functioning of the European Union. OJ C 326, 26 $6^{\text {th }}$ October 2012, pp. 47-390.

31 For more on CJEU's preliminary ruling procedure, see Craig, P., de Búrca, G., EU Law : 
important differences and similarities between the preliminary ruling procedure under the jurisdiction of the CJEU, and advisory opinion proceedings established with the Protocol No. 16.

The main procedural difference between the two proceedings is the determination of national courts, which can request a decision. The preliminary ruling procedure is available to all national courts or tribunals at all levels in any EU Member State, ${ }^{32}$ making it broader in application than the new Protocol No. 16 mechanism, which is applicable only to those State Parties to the ECHR that have ratified the Protocol and only to their highest national courts and tribunals.

There are also a few substantive differences, the first one being the objective of the proceedings. The objective of the preliminary ruling procedure is to guarantee uniform interpretation of EU law, ${ }^{33}$ while the objective of the Protocol No. 16 is to provide domestic courts with guidance on interpreting the ECHR and providing a new means to facilitate dialogue between the two. Second important substantive difference is the nature of the question that needs to be addressed by the European judicial authorities. In the context of the preliminary ruling procedure, national courts may present questions about the interpretation and validity of EU law to the CJEU if they consider the question necessary to their judgment, ${ }^{34}$ a narrower scope than the one established with Protocol No. 16, which only provides that national courts may request an advisory opinion on questions of principle relating to the interpretation or application of the rights and freedoms defined in the ECHR or the protocols thereto that are raised in the context of a pending case. And finally, national court or tribunal against whose decision there is no judicial remedy has an obligation to refer a case to the CJEU concerning a question of EU law. ${ }^{35}$ As stated above, Protocol No. 16 provides domestic courts only with a possibility to request an advisory opinion and therefore contains no provisions on obligatory request for such an opinion.

Interestingly, the CJEU has established that when a provision in the EU law is so clear as to leave no scope for reasonable doubt, or where previous decisions of the CJEU have already dealt with the point of law in question, the last instance national court or tribunal has discretion as any other national court or tribunal to refer a case (doctrine of acte clair). ${ }^{36}$ Such a practical solution, which aims at reducing the CJEU's caseload, is worth considering by the ECtHR when deciding on whether to grant a request for advisory opinion which only raises questions that already have an answer in the ECtHR's case law.

Text, cases and materials, $6^{\text {th }}$ edition, Oxford, Oxford University Press, 2015, pp. 464-508; Fairhurst, J., Law of the European Union, $7^{\text {th }}$ edition, Essex, Pearson Education Limited, 2010, pp. 189-213; Trstenjak, V., Brkan, M., Pravo EU : Ustavno, procesno in gospodarsko pravo EU, Ljubljana, GV Zalobža, 2018, pp. 252-289; Varanelli, L., Predhodno odločanje v evropskem pravu, Ljubljana, Uradni list Republike Slovenije, 2010; Brkan, M. et al. (ed.), Postopki pred Sodiščem EU, Ljubljana, GV Založba, 2014.

32 Article 267(2) TFEU.

33 CJEU, Recommendations to national courts and tribunals in relation to the initiation of preliminary ruling proceedings (2018/C $257 / 01), 20^{\text {th }}$ July 2018 , para. 1.

34 Article 267(2) TFEU.

35 Article 267(3) TFEU.

36 Case C-283/81 CILFIT v. Ministry of Health [1982] ECR 3415, paras. 14-16. 
Overall, based on the numerous differences among the two institutes which were illustrated above, the authors believe the advisory opinion proceedings established with Protocol No. 16 will not impact the CJEU's preliminary ruling procedure due to different legal nature and purpose of both procedures.

\subsubsection{European Union and accession to Protocol No. 16}

In the relationship between the CJEU and the ECtHR, it is clear that the ECHR norms are already integrated into EU law. The EU Charter of Fundamental Rights (hereinafter referred as the Charter) ${ }^{37}$ effectively incorporates the ECHR norms into EU law and contains strict instructions for EU law to respect the ECHR. The Treaty of Lisbon further provides that the Charter has the same value as the Treaties and Article 6(2) of the Treaty of European Union ${ }^{38}$ provides a duty for the EU to accede to the ECHR. Such accession would have the effect of formally incorporating the ECHR into the EU legal order, and of subjecting the EU institutions, including the CJEU, to the decisions and judgments of the ECtHR. However, the CJEU delivered a negative opinion in relation to the compatibility of the Draft Accession Agreement with the Treaties and Protocol No. 8 EU, ${ }^{39}$ known as Opinion 2/13.40

In the third section of the Opinion 2/13, the CJEU focused on the Protocol No. 16 to the ECHR and compared its provisions with the EU law obligation for such highest courts to refer cases on EU law to the CJEU under the preliminary rulings system. The main conclusions were:

- the mechanism established by the Protocol No. 16 could affect the autonomy and effectiveness of the preliminary rulings procedure, since ECHR would after accession - form an integral part of EU law, ${ }^{41}$

- a request for an advisory opinion made pursuant to Protocol No. 16 could trigger the procedure for the prior involvement of the CJEU, thus creating a risk that the preliminary ruling procedure might be circumvented, ${ }^{42}$ and

- since there is no provision in respect of the relationship between the mechanism established by Protocol No. 16 and the preliminary ruling procedure, national courts might be tempted to turn to the ECtHR for an advisory opinion rather than request a preliminary ruling from the CJEU.

For the abovementioned reasons, the CJEU concluded that the Accession Agreement is liable adversely to affect the autonomy and effectiveness of the preliminary ruling procedure. ${ }^{43}$

37 Charter of Fundamental Rights of the European Union, OJ C 326, 26.10.2012, pp. 391-407.

38 Consolidated version of the Treaty on European Union, OJ C 326, 26 ${ }^{\text {th }}$ October 2012, pp. $13-$ 390.

39 Protocol (No 8) relating to Article 6(2) of the Treaty on European Union on the accession of the Union to the European Convention on the Protection of Human Rights and Fundamental Freedoms, OJ C 326, 26 $6^{\text {th }}$ October 2012, p. 273.

40 Opinion 2/13 pursuant to Article 218(11) TFEU, ECLI:EU:C:2014:2454, European Union: Court of Justice of the European Union, $18^{\text {th }}$ December 2014.

41 Opinion 2/13 of the CJEU, para. 197.

42 Opinion $2 / 13$ of the CJEU, para. 198.

43 Opinion 2/13 of the CJEU, para. 199. 
Nevertheless, it has been stressed in legal theory that it is not clear what interest would a national highest court have in requesting an advisory opinion from the ECtHR, rather than a preliminary ruling from the CJEU, since the latter is typically speedier, it provides for the possibility to request an interpretation of the EU provisions in question beyond their compatibility with fundamental rights and it might also lead to a more satisfactory result given that the CJEU would still remain the only court which might declare an act of the EU institutions invalid. ${ }^{44}$ The theory also warns that a mere "taking account" of ECtHR case law by the CJEU will effectively send the message that, in the sphere of human rights protection, the two courts are equal, and that the ECHR and the Charter are equivalent documents, which could - with the EU law's claims to supremacy and direct effect - be read as undermining the ECtHR's core judicial function. ${ }^{45}$ The authors believe that the Opinion 2/13, especially in the abovementioned part, mainly focuses on securing the autonomy of CJEU in its relationship to ECtHR, without having regard to possible cooperation between these two courts in order to raise the level of effective protection of the human rights standards across Europe.

\section{INTENDED EFFECTS OF ADVISORY OPINIONS}

\subsection{The judicial dialogue between national courts and the ECtHR in some European countries}

With ratifying the ECHR, the States have committed themselves to securing for everyone within their jurisdiction both human rights and fundamental freedoms, which fall into the scope of the protection of this international instrument. Nevertheless, Article 1 of the ECHR does not require States to incorporate the ECHR directly into national law and thereby make it directly applicable before domestic courts, ${ }^{46}$ which was also confirmed by the ECtHR. ${ }^{47}$ Still, the reception of the ECHR into the domestic legal order and the judicial dialogue between the ECtHR and national supreme courts are intrinsically linked. ${ }^{48}$

At first, national constitutional courts were reluctant to incorporate the ECHR into their national legal systems and the resistance only started yielding in the 1980s, and particularly in the past ten years of the 21 st century. ${ }^{49}$ Nevertheless, the ECHR

44 Spaventa, E., A very fearful Court? The protection of fundamental rights in the European Union after Opinion 2/13, Maastricht, Maastricht journal of European and comparative law, vol. 22, 1/2015, p. 49.

45 Eeckhout, P., Opinion 2/13 on EU Accession to the ECHR and Judicial Dialogue: Autonomy or Autarky, New York, Fordham International Law Journal, vol. 38, 4/2015, p. 991.

46 Schabas, W. A., op. cit., p. 90.

47 Swedish Engine Drivers' Union v. Sweden, no. 5614/72, 6 February 1976, para. 50.

48 Rinceanu, J., Judicial dialogue between the European Court of Human Rights and national supreme courts, in: Spinellis, C. et al., Europe in Crisis: Crime, Criminal Justice, and the Way Forward. Essays in honour of Nestor Courakis. Vol. II: Essays in English, German, French, and Italian, Athens, 2017, pp. 1032-1033.

49 Nastić, M., ECHR and National Constitutional Courts, Niš, Zbornik radova Pravnog fakulteta u Nišu, vol. 71, 14/2015, p. 206. 
has gradually infiltrated in the national human rights' protection systems, with constitutional courts having had a key role in this process due to their realization that reliance on the ECHR could strengthen their authority on the national level..$^{50}$ Today, the ECtHR exercises substantial influence on the national legal systems of the States and has therefore evolved into an important promoter of common human rights standards..$^{51}$ The ECtHR regards the ECHR as a constitutional instrument of the European public order and despite the subsidiary role the ECtHR is supposed to play in human rights protection, its position has changed into that of a 'constitutional court' under the ECHR system. ${ }^{52}$

The judicial dialogue between national courts and the ECtHR is characterized by a shared responsibility, meaning that national courts have the most important role to play in guaranteeing the primary protection of the ECHR, while the ECtHR only has a supervisory role and decides in individual cases whether a State has complied with its obligation of human rights protection..$^{53}$ Although, according to Article 46(1) of the ECHR, the ECtHR's judgments have an inter partes effect, it has become accepted that ECtHR's interpretations of the terms and concepts contained in the ECHR have an erga omnes effect, which implies that all national authorities have to comply with the ECHR as interpreted by the ECtHR through its case law. ${ }^{54}$ Due to the binding nature of the ECtHR's interpretations, a uniform level of protection of human rights within the 47 Member States can be ensured. ${ }^{55}$

While up to the adoption of Protocol No. 11 to the ECHR ${ }^{56}$ the common aim of

50 loc. cit.

51 Rinceanu, J., Judicial dialogue between the European Court of Human Rights and national supreme courts, in: Spinellis, C. et al., Europe in Crisis: Crime, Criminal Justice, and the Way Forward. Essays in honour of Nestor Courakis. Vol. II: Essays in English, German, French, and Italian, Athens, 2017, p. 1041.

52 Grabenwarter, C., The European Convention on Human Rights: Inherent Constitutional Tendencies and the Role of the European Court of Human Rights, Budapest, Elite Law Journal, vol. 2, 1/2014, p. 102. See also: Zoethout, C. M., The European Court of Human Rights and Transnational Judicial Dialogue, Vienna, Vienna Journal on International Constitutional Law, vol. 9, 3/2015, pp. 409-410.

53 Copenhagen Declaration, adopted at High Level Conference meeting in Copenhagen on 12 and 13 April 2018 at the initiative of the Danish Chairmanship of the Committee of Ministers of the Council of Europe, paras. 6-11.

54 Lambert-Abdelgawad, E., The Execution of Judgments of the European Court of Human Rights, Strasbourg, Council of Europe Publishing, 2002, pp. 7-8. See also Gerards, J., The European Court of Human Rights and the National Courts: giving shape to the notion of "shared responsibility", in: Gerards, J., Fleuren, J., op. cit. p. 23.

55 Rinceanu, J., Judicial dialogue between the European Court of Human Rights and national supreme courts, in: Spinellis, C. et al., Europe in Crisis: Crime, Criminal Justice, and the Way Forward. Essays in honour of Nestor Courakis. Vol. II: Essays in English, German, French, and Italian, Athens, 2017, pp. 1039-1040.

56 Protocol No. 11 to the ECHR entered into force on November 1998 and has superseded the Protocols 2, 3, 5, 8, 9 and 10. Protocol no. 11 aims to rationalise the machinery for enforcement of rights and liberties guaranteed by the Convention. The Protocol abolished the Commission, allowing individuals to apply directly to the ECtHR, which was given compulsory jurisdiction and altered the latter's structure. The protocol also abolished the judicial functions of the Committee of Ministers. 
the States, the ECtHR as well as the political organs of the Council of Europe was to create and strengthen the ECtHR's function as the arbiter of individual human rights complaints, the focus has shifted in the last decade - due to the overwhelming workload and the growing criticism of some States concerning the ECtHR's activism, new strategies were developed to bolster the ECtHR's authority and its effectiveness at the national level and an adequate conceptualization of the ECtHR's future role within the multi-level institutional framework was discussed among the stakeholders. ${ }^{57}$ One of results of this endeavor was the adoption of Protocol No. 16, which created a path for the ECtHR and national courts do deepen their judicial dialogue and thus consolidate the understanding of the human rights' and fundamental freedoms' protection in the whole Europe.

In what follows, the authors will present the main highlights of the judicial dialogue between national courts and ECtHR in Belgium, Sweden and Italy. The countries were selected due to their different approaches to the judicial dialogue and their implementation of the ECtHR case law into the national decision-making process.

\subsubsection{Belgium}

The Belgian Constitutional Court stands out with a particular reliance on the ECtHR decisions in its reasoning - sometimes it refers to more than fifteen ECtHR decisions in the same judgment. ${ }^{58}$ Paul Martens, then President of the Constitutional Court, emphasized how the Constitutional Court, "without even the slightest inclination to resist" is willing to reverse its own case law in order to comply with the ECtHR, and is prepared to suspend its decisions to await the outcome of the ECtHR proceedings. ${ }^{59}$ For example, when the Belgian Constitutional Court had to decide on whether the Electoral Code, which temporarily disenfranchised those convicted to a prison sentence of four months or more, violated the Constitution, the Constitutional Court postponed its deliberations in order to await the outcome of the Grand Chamber decision in the Hirst v. the United Kingdom (no. 2) ${ }^{60}$ case. ${ }^{61}$ It then decided that the Constitution was violated, because convicted persons were automatically deprived of the right to vote for a term that lasted much longer than the term of the sentence. ${ }^{62}$ As a consequence, Parliament abolished the automatic disenfranchisement in these cases, ${ }^{63}$ which shows that eagerness of the Constitutional Court to comply with ECHR's

57 Jahn, J., Normative Guidance from Strasbourg Through Advisory Opinions: Deprivation or Relocation of the Convention's Core?, Heidelberg, Zeitschrift für ausländisches öffentliches Recht und Völkerrecht $($ ZaöRV) $=$ Heidelberg journal of international law (HJIL), vol. 74, 4/2014, p. 822.

58 Popelier, P., Belgium: faithful, obedient, and just a little irritated, in: Popelier, P. et al. (eds.), Criticism of the European Court of Human Rights: shifting the convention system : counterdynamics at the national and EU level, Cambridge, Intersentia, 2016, pp. 117-118.

59 Popelier, P., op. cit., p. 118.

60 Hirst v. the United Kingdom (no. 2) [GC], no. 74025/01, 6 October 2005.

61 loc. cit.

62 loc. cit.

63 loc. cit. 
standards sometimes results in adjustments at the political level.

The Court of Cassation also gives explicit priority to the ECHR over the Belgian Constitution and considers the judgments of the ECtHR to have res interpretata effect, meaning that the Belgian courts have to comply with these judgments, even if Belgium was not party in the case. ${ }^{64}$ Nevertheless, the practice of the Court of Cassation is more distant compared to the Constitutional Court, especially because the Court of Cassation seems to often disregard the ECtHR case law or refers to it only in abstracto, without quoting specific judgments. ${ }^{65}$

\subsubsection{Sweden}

In 1995, Sweden chose to incorporate the whole Convention and its Protocols into its national legal system. Even though the incorporation law provides that the ECHR is to have the status of an ordinary law, a constitutional provision was also added, which determines that )a law or other regulation shall not be issued in conflict with Sweden's obligations under [the ECHR]. « ${ }^{66}$ Sweden has two supreme judicial bodies, i. e. the Supreme Court and the Supreme Administrative Court, for which the ECHR and the ECtHR case law normally form an important part of the argumentation in cases involving fundamental rights. ${ }^{67}$ Given that, the Swedish legal framework in some cases still seems to be superior to ECHR when it comes to court's reasoning, which can be seen from the Supreme Court case NJA 2005 s. $805 .{ }^{68}$ In this case the Supreme Court assessed the situation first under the relevant national criminal law, then in relation to national constitutional law, and in the end to the ECHR and the ECtHR case law. ${ }^{69}$ This method, which is normally applied also by the Supreme Administrative Court, can be interpreted as regarding the ECHR as a supplement to the domestic legislation. ${ }^{70}$

Nevertheless, there have been some developments in the last decade, shifting into a direction of taking a greater account of the ECtHR case law. Both Supreme Courts have introduced a doctrine of »clear support«, which provides Swedish national courts with the ability to set aside an act of law which violates the ECHR, also in situations when the matter has not yet been assessed by the ECtHR. ${ }^{71}$ For example, in a criminal case relating to tax offences (NJA 2010 s. 168 I-II), ${ }^{72}$ the Supreme Court underlined the responsibility of the legislature to make sure that

64 Popelier, P., op. cit., p. 121.

65 Popelier, P., op. cit., p. 122.

66 Cameron, I., The Swedish Experience of the European Convention on Human Rights since Incorporation, Cambridge, The International and Comparative Law Quarterly, vol. 48, 1/1999, p. 23.

67 Wenander, H., Sweden: European Court of Human Rights endorsement with some reservations, in: Popelier, P., et al., Criticism of the European Court of Human Rights: shifting the convention system: counter-dynamics at the national and EU level, Cambridge, 2016, p. 261.

68 The Supreme Court of Sweden, NJA 2005 s. 805 from 29 ${ }^{\text {th }}$ November 2005.

69 Wenander, H., op. cit., p. 261.

70 loc. cit.

71 Wenander, H., op. cit., p. 258.

72 The Supreme Court of Sweden, NJA 2010 s. 168 I-II from 31 $1^{\text {th }}$ March 2010. 
Swedish legislation follows the ECHR concerning more systemic matters. ${ }^{73}$ However, the Supreme Court later limited the effects of the "clear support" requirement and elaborated that factors such as the importance of the right, the type of legislation, the legal and practical consequences, as well as the opportunities for the legislature to adapt Swedish legislation to the ECHR need to be taken into account. ${ }^{74}$ This decision has been seen in the legal theory as an attempt to promote a certain degree of judicial restraint concerning the impact of ECtHR case law. ${ }^{75}$ Nevertheless, Swedish legal theory stresses that the legalistic approach, which is an integral part of Swedish legal culture, implies that the ECHR as well as the case law of the ECtHR is respected and that there have not been any discussions implying that a Swedish court should simply disregard the ECtHR judgement. ${ }^{76}$

\subsubsection{Italy}

In the course of the constitutional reform of 2001, Article 117 of the Italian Constitution was reformulated so as to provide that the state and the regions exercise their legislative power in compliance with the Constitution and with the constraints deriving from EU legislation and international obligations $«{ }^{77}$ This reform set the stage in 2007 for the Constitutional Court to overrule its previous case law and state that the ECHR is placed in an intermediate position between the Constitution and ordinary domestic law. ${ }^{78}$ In the event that judges in common courts found domestic legislation to be incompatible with the ECHR, it became possible for them to refer the case to the Constitutional Court on the basis of the violation of the ECHR, which bolstered the ability of the domestic judge to enter into a formal, although indirect, vertical dialogue with the ECtHR.$^{79}$ The potential for dialogue was further strengthened by the Constitutional Court's ruling that the ECtHR's interpretation of the ECHR has binding effect and that domestic judges can therefore not interpret the ECHR differently than the ECtHR. ${ }^{80}$ However, the Constitutional Court introduced a doctrine applicable to possible inconsistencies between Italian law and the ECHR: the doctrine of »enlarged counter-limitations «, under which the Constitutional Court preserved for itself the power to verify whether the ECHR, as interpreted by the ECtHR, was consistent with all other constitutional values. ${ }^{81}$ Only then would it declare the domestic law

73 Wenander, H., op. cit., p. 257.

74 The Supreme Court of Sweden, NJA 2013 s. 502 from 11 th June 2013; Wenander, H., op. cit., p. 258.

75 Wenander, H., op. cit., p 259.

76 loc. cit.

77 Sabato, R., Judicial dialogue: The experience of Italy, in: Müller, A. (ed.), Judicial dialogue and human rights, Cambridge, Cambridge University Press, 2017, p. 273.

78 loc. cit.

79 loc. cit.

80 Glas, L. R., The Boundaries to Dialogue with the European Court of Human Rights, in: Benedek, W., et al. (eds.), European Yearbook on Human Rights, Cambridge, Intersentia, 2018, p. 302.

81 Sabato, R., op. cit., p. 273. 
unconstitutional as a result of a direct violation of the ECHR. ${ }^{82}$

In March 2015, the Constitutional Court adopted a different, somewhat restrictive approach as before. ${ }^{83}$ While it reaffirmed common judges' general obligation to interpret Italian law consistently in light of the ECHR and ECtHR case law, it further stated that, when doing so, common judges should nonetheless give priority to a reading of domestic law that is in accordance with the Constitution, which is »axiologically dominant» over the ECHR ${ }^{84}$ Also, the Italian Constitutional Court declared that common judges are bound by ECtHR case law only in a limited number of circumstances ${ }^{85}$ and only in these instances should they refer cases to the Constitutional Court for this Court to verify whether the obligation to conform to Article 117 of the Italian Constitution or to »counter-limitations« prevails over ECHR-consistent interpretation. ${ }^{86}$ The authors believe that such a decision does not contribute to raising the human rights standards, since it encourages national judges to prioritize national law over the international obligations.

\subsection{Consideration of intended effects of advisory opinions on same recent national court cases}

It appears very difficult to make a comprehensive consideration of intended effects of advisory opinions when no advisory opinion has been issued until today. Therefore, the authors decided to look into same recent court cases of particular European states and assess whether initiating the advisory opinion procedure (if existed at the time of adopting the court decision) would have changed final national courts' decisions and consequently prevented the occurrence of violation of human rights and fundamental freedoms.

\subsubsection{The case of Produkcija Plus storitveno podjetje d.o.o. v. Slovenia}

Protection of human rights and fundamental freedoms in Slovenia is inseparably linked to triangle, which consists of three vertices: i) the Constitution and the Constitutional Court, ii) the ECHR and the ECtHR ${ }^{87}$ and iii) the Charter of Fundamental Rights of the European Union and the CJEU. The relations within this triangle are modifying dynamically, however, all the above-mentioned courts are inclined to extensive, creative and developmental interpretation of the documents which form a basis for their decision-making. Generally, the Slovenian legal theory

82 Sabato, R., op. cit., p. 274.

83 The Constitutional Court of the Italian Republic, judgment no. 49, 14 ${ }^{\text {th }}$ January 2015.

84 Sabato, R., op. cit. pp. 274-275.

85 More specifically, the judges should only follow pilot judgments, judgments concerning 'a specific individual dispute remitted to the national court' and well-established case-law. Glas, L. R., op. cit., p. 303.

86 Sabato, R., op. cit., p. 275.

87 In the last six-year period (2013-2018), ECtHR has found a violation in 43 cases against Slovenia, while it has found violations in 56 cases in the prior six-year period (2007-2012), meaning that, in comparison to the latter time period, the number of determined violations against Slovenia has been reduced by $23 \%$ in the last six years. 
advocates for such collaboration among the Constitutional Court, the ECtHR and the $\mathrm{CJEU}$ as to lead to higher standards of the human rights protection. ${ }^{88}$

In a recent surprising statement, which has soon been withdrawn from the official web page due to public backlash, the Supreme Court of the Republic of Slovenia (hereinafter referred as the Supreme Court) has publicly disapproved with the ECtHR's findings in the case of Produkcija Plus storitveno podjetje d.o.o. v. Slovenia ${ }^{89}$ where ECtHR found a violation of Article 6 of the ECHR. A significant part of the public, including some of the most prominent Slovenian lawyers, understood the court's statement as a general refusal to follow the ECtHR`s decision which occurred for the first time in Slovenia. Later, the Supreme Court decided to withdrawn its statement and regretted the tone in which the statement was written, saying that it is aware of the important role the ECtHR plays promoting and enforcing human rights in the Council of Europe's territory. ${ }^{90}$ In the present case finding violation of Article 6 of the ECHR was undoubtedly the consequence of the fact that Slovenian national legal procedures were not in line with the ECtHR's established case-law standards on oral hearings.

\subsubsection{Facts of the case}

The case Produkcija Plus storitveno podjetje d.o.o. v. Slovenia concerned proceedings against the applicant company, Produkcija Plus storitveno podjetje d.o.o. for alleged abuse of its dominant position, which was initiated by the Competition Protection Office (later: the Competition Agency). After an unsuccessful inspection of the applicant's premises by the Competition Office, an inspection report was issued, in which the Competition Office fined the applicant 105,000 euros for obstructing the inspection. The applicant appealed and requested an oral hearing but the Supreme Court dismissed the action. The applicant company complained in particular, under Article 6 (right to a fair trial), that the proceedings imposing a fine for obstructing the inspection had been unfair because of the lack of oral hearings. ${ }^{91}$

The ECtHR pointed out that the Supreme Court was the first and only tribunal to examine the applicant company's case and as such it was required under Article 6(1) of the ECHR to examine not only legal aspects of the case but to review the facts on which the applicant company's punishment was based and which the applicant company disputed. However, the Supreme Court made no reference to any other

88 See: Ribičič, C., Ustavno sodišče - ESČP - Sodišče EU, Ljubljana, Podjetje in delo, vol. 36, 6-7/2010, pp. 1054-1061; id., Razbremenjevanje ESČP in Ustavnega sodišča, Ljubljana, Podjetje in delo, vol. 33, 6-7/2007, pp. 993-1004; id., Zakaj podpiram reformiranje ESČP?, Ljubljana, vol. 22, 12/; pp. I-III; Ribičič, C., Kaučič, I., Referendum and The European Convention on Human Rights, Regensburg, Entwicklungen im Europäischen Recht, vol. 11, 1/2016, pp. 31-59; Žuber, B., Ustavnosodni nadzor zakonodajnega referenduma, Ljubljana, GV Založba, 2018, p. 69-250.

89 Produkcija Plus storitveno podjetje d.o.o. v. Slovenia, no. 47072/15, 23 October 2018.

90 Vrhovno sodišče po plazu kritik umaknilo sporno sporočilo v zadevi Pro Plus, <http://www. rtvslo.si/slovenija/vrhovno-sodisce-po-plazu-kritik-umaknilo-sporno-sporocilo-v-zadevi-proplus/470349>, $29^{\text {th }}$ of October 2018, $6^{\text {th }}$ of November 2018.

91 For more on the other alleged violations, see Produkcija Plus storitveno podjetje d.o.o. v. Slovenia, no. 47072/15, 23 October 2018, para. 32. 
evidence than the impugned decision itself and did not hear the evidence requested by the applicant company aimed at proving the opposite. Furthermore, despite the applicant company expressly requesting that a hearing be held, the Supreme Court neither acknowledged the request nor gave any reasons for not granting it. In view of the above, the ECtHR found that the applicant company was deprived of a right to have the factual aspects of the administrative decision issued against it reviewed by the tribunal with full jurisdiction and that there has accordingly been a violation of Article 6(1) of the ECHR. ${ }^{22}$

\subsubsection{Would the advisory opinion on oral hearing have prevented the violation of Article 6 of ECHR?}

As already mentioned above, the Supreme Court, in its statement regarding Produkcija Plus storitveno podjetje d.o.o. v. Slovenia ${ }^{93}$ asserted that the ECtHR's argumentation is unconvincing, since there is no grounds in Slovenian legislation for the obligatory oral hearing in front of the Supreme Court in the given case. The Slovenian Prevention of the Restriction of Competition Act has a clear provision, which states that the court generally decides without conducting a public hearing. ${ }^{94}$ Furthermore, the Supreme Court stated that the concerned fine was given in the accordance with the Prevention of the Restriction of Competition Act and cannot be equated with a fine, given in the misdemeanor procedure. Therefore, the given monetary penalty cannot be regarded as a criminal procedure in accordance with the Article 6(1) of the ECHR, which would otherwise require a conduct of an oral hearing.

If we focus on the question, whether it would be possible to prevent the violation and consequently the surprising statement of the Supreme Court there seems to be various options. First, the Supreme Court could have requested initiation of the procedure under Article 23 of the Slovenian Constitutional Court Act substantiating that Article 59 of Prevention of the Restriction of Competition Act cannot be interpreted and applied in a constitutionally consistent manner. Under Article 23 of the Constitutional Court Act the Constitutional Court intervenes only when national courts substantiate that the challenged statutory provision cannot be interpreted and applied in a constitutionally consistent manner and that, consequently, in the concrete proceedings the court cannot adopt a constitutionally consistent decision without the decision of the Constitutional Court on the unconstitutionality of the law at issue. ${ }^{95}$ In the present case it is not very likely the Constitutional Court would

92 For more on the ECtHR's decision, see Produkcija Plus storitveno podjetje d.o.o. v. Slovenia, no. 47072/15, 23 October 2018, paras. 51-60.

93 The statement has since been removed and it is not publicly accessible anymore. However, parts of it can still be found in the Slovenian media. For example, see Boštele, M., Vrhovno sodišče: Argumentacija ESČP je neprepričljiva, <https://www.delo.si/novice/slovenija/ vrhovno-sodisce-argumentacija-escp-je-neprepricljiva-106336.html $>, 25^{\text {th }}$ of October $2018,6^{\text {th }}$ of November 2018.

94 Article 59 of the Prevention of the Restriction of Competition Act reads as follows: "The court shall, as a rule, decide without a hearing".

95 For more on this see: Constitutional Court of the Republic of Slovenia, U-I-238/12 from $23^{\text {rd }}$ January 2014. 
have initiated the procedure and decide on the merits as public hearing in line with Article 59 is not expressly but generally prohibited, and could have be performed if the Supreme Court decided so in the present case. Therefore, the Constitutional court would have probably concluded the Supreme Court could adopt a constitutionally consistent decision without the Constitutional Court's intervention. Even though the Constitutional Court is competent to decide on compliance of a national law with the ratified national treaties ${ }^{96}$ and is authorized to apply the ECHR standards regarding the oral hearing in this matter and deliver a decision, it needs to be pointed out that, in accordance with ECtHR's case law, the obligation under Article 6(1) of ECHR to hold a public hearing is not an absolute one and a hearing may not be necessary due to exceptional circumstances of the case, for example when it raises no questions of fact or law which cannot be adequately resolved on the basis of the case-file and the parties' written observations. ${ }^{97}$ This leads us to conclusion that the Constitutional Court also if it decided on merits of the case would not have been likely to found a non-compliance of the Article 59 of Prevention of the Restriction of Competition Act with the ratified national treaty (ECHR), which is hierarchically placed under the Constitution in accordance with the Slovene legal order. ${ }^{98}$ In light of the above, the second option for preventing the violation of Article 6 is the present case would be adopting the Supreme Court's decision after the public hearing. ${ }^{99}$

The third option assumes the existence of the advisory opinion proceeding at the time of the court proceeding. The Supreme Court could have, as one of the highest national courts, ${ }^{100}$ requested the ECtHR to give an advisory opinion. Presumably, two questions of principle would have arisen in the case: firstly, the obligation of conducting an oral hearing in the light of the relevant national provisions, and secondly, the existence of a "criminal charge" in this matter. Since the ECtHR's case law on these questions is already well established, ${ }^{101}$ it is possible to make a conclusion that the Grand Chamber would have refused to accept the request into consideration.

96 See Article 21(1)(2) of the Constitutional Court Act.

97 Lundevall v. Sweden, no. 38629/97, 12 November 2002, para. 34; Motion Pictures Guarantors Ltd v. Serbia, no. 28353/06, 8 June 2010, paras. 30-31; Suuripää v. Finland, no. 43151/02, 12 January 2010, para. 39.

98 See Article 153(2) of the Constitution of the Republic of Slovenia.

99 This option assumes the Supreme Court would waive long lasting practice's interpretation of Article 59 of Prevention of the Restriction of Competition Act (that is the competent court always adopts decision without public hearing).

100 As the highest courts and tribunals which can request the advisory opinion in accordance with Article 1(1) od the Protocol No. 16, Slovenia has determined its Constitutional Court and Supreme Court. See Article 3 of the Act Ratifying Protocol No. 16 to the Convention for the Protection of Human Rights and Fundamental Freedoms (Official Gazette - International Treaties, no. 1/15).

101 For more on standards for conducting an oral hearing, see, among others, Salomonsson $v$. Sweden, no. 38978/97, 12 November 2002, paras. 34-40; Miller v. Sweden, no. 55853/00, 8 February 2005, paras. 29-37; Jussila v. Finland [GC], no. 73053/01, 23 November 2006, paras. 40-45. For more on term »criminal charge «, see, among others, Engel and Others $v$. the Netherlands, nos. 5100/71, 5101/71, 5102/71, 5354/72 and 5370/72, 8 June 1976, paras. 80-85; Lutz v. Germany, no. 9912/82, 25 August 1987, paras. 50-57; Bendenoun v. France, no. 12547/86, 24 February 1994, paras. 44-48. 
However, if the ECtHR had issued an advisory opinion in this matter, the Supreme Court would have conducted the proceeding in accordance with the ECHR standards and thus avoided the finding of a violation by the ECtHR. Also, with an advisory opinion and its erga omnes effect regarding interpretation of the ECHR standards, Slovenian courts could have acted in accordance with the requests for conducting an oral hearing beforehand and therefore avoid being convicted twice in the same year for non-compliance with the mentioned obligations. ${ }^{102}$ And lastly, it is possible to assume that the national legislator would have regarded such an opinion as a basis for amending the provisions, which apply to the oral hearing.

Overall, the abovementioned statement of the Supreme Court was, without a doubt, inappropriate. Nevertheless, the authors believe the timely European judicial dialogue could have contributed to its avoidance. If we put ourselves in the shoes of the Supreme Court, it is not difficult to understand its defense in the situation, being the consequence of the surprise when the judgment was issued, given that the ECtHR has interpreted relevant Slovenian legislation on its own. However, it is possible to speculate that the advisory opinions will help with preventing such situations in the future, making possible for both participants of the judicial dialogue to form convincing legal arguments to appeal to the reasoning of the other side and therefore contribute to improvement of understanding of the ECHR standards and raise the level of protection of human rights and fundamental freedoms all over Europe.

\subsubsection{Case of Paposhvili v. Belgium}

The case of Paposhvili v. Belgium ${ }^{103}$ has been selected by the authors due to its importance on protection of seriously ill aliens, who are facing a removal into a country of origin. What is more, with the analysis of the events unfolding on a national level, the authors will demonstrate how the development of the national case law in favor of such aliens could have raised the human rights standards years before the decision in Paposhvili case was adopted, if the advisory opinion proceedings had existed at that point in time.

\subsubsection{Facts of the case}

The applicant was a Georgian national who lived in Brussels and was there diagnosed with a number of serious medical conditions, for which he received hospital treatment. Later, the Minister for the Interior issued a deportation order directing the applicant to leave the country. Relying, amongst others, on Articles 2 (right to life) and 3 (prohibition of inhuman or degrading treatment), the applicant alleged that if he had been expelled to Georgia he would have faced a real risk there of inhuman and degrading treatment and of a premature death.

The ECtHR noted that Mr Paposhvili had been suffering from a life-threatening

102 For more on this, see Žuber, B. et al. (ed.), Pomen prakse in zahtev ESČP za izvedbo glavne obravnave v upravnem sporu: študija projekta. Ljubljana, Pravna fakulteta, Univerza v Ljubljani, 2018.

103 Paposhvili v. Belgium [GC], no. 41738/10, 13 December 2016. 
illness and that his condition had become stable as a result of the treatment he was receiving in Belgium. If the treatment had been discontinued, his life expectancy would have been less than six months. The applicant had made requests for regularisation of his residence status in Belgium on medical grounds, on the basis of section 9ter of the Aliens Act. However, the requests had been refused on the grounds of the serious crimes he had committed.

The ECtHR concluded that the domestic authorities had not made any assessment of the risk facing Mr Paposhvili and the information available to those authorities had been insufficient for them to conclude that the applicant, if returned to Georgia, would not have run a real and concrete risk of treatment contrary to Article 3 of the Convention.

\subsubsection{Could the existence of advisory opinion proceeding have raised the human rights standards sooner?}

The crux of this case was whether Article 3 of the ECHR also applied to situations of inhuman or degrading treatment of seriously ill aliens on account of the lack of appropriate treatment in the receiving country. At that point in time, only two relevant ECtHR judgments existed - N. v. the United Kingdom (2008) ${ }^{104}$ and D. v. the United Kingdom (1997) ${ }^{105}$ - which both contained only a general ruling that in addition to situations of removal of seriously ill aliens in which death was imminent, there might be other very exceptional cases where the humanitarian considerations weighing against removal were equally compelling.

Already two years before the judgment of the Grand Chamber was delivered, the

104 In the case of $N$. v. the United Kingdom ([GC], no. 26565/05, 27 May 2008), which concerned the removal of a Ugandan national who was suffering from Aids to her country of origin, the ECtHR observed that neither the decision to remove an alien who was suffering from a serious illness to a country where the facilities for the treatment of that illness were inferior to those available in the Contracting State, nor the fact that the individual's circumstances, including his or her life expectancy, would be significantly reduced, constituted in themselves "exceptional" circumstances sufficient to give rise to a breach of Article 3. Regard should be had to the fact that the applicant's condition was not critical and was stable as a result of the treatment she had received in the United Kingdom, that she was fit to travel and that her condition was not expected to deteriorate as long as she continued to take the treatment she needed. Nevertheless, the ECtHR specified that, in addition to situations of the kind in which death was imminent, there might be other very exceptional cases where the humanitarian considerations weighing against removal were equally compelling.

105 In D. v. the United Kingdom (no. 30240/96, 2 May 1997), which concerned the decision taken by the United Kingdom authorities to expel to St. Kitts an alien who was suffering from Aids, the ECtHR considered that the applicant's removal would expose him to a real risk of dying under most distressing circumstances and would amount to inhuman treatment. It found that the case was characterised by "very exceptional circumstances", owing to the fact that the applicant suffered from an incurable illness and was in the terminal stages, that there was no guarantee that he would be able to obtain any nursing or medical care in St. Kitts or that he had family there willing or able to care for him, or that he had any other form of moral or social support. Taking the view that, in those circumstances, his suffering would attain the minimum level of severity required by Article 3, the ECtHR held that compelling humanitarian considerations weighed against the applicant's expulsion. 
case law regarding the abovementioned issue has developed significantly in Belgium. This case law concerns the application of section 9ter, paragraph $1,{ }^{106}$ to aliens who have not been excluded a priori from the scope of that provision.

A Dutch-speaking Division of the Conseil d'Etat held that, irrespective of the scope of application of Article 3 of the ECHR, section 9ter was clear and applied to situations going beyond a direct threat to the life of the applicant or the existence of a critical condition, ${ }^{107}$ and therefore also covered a real risk of inhuman or degrading treatment on account of the absence of appropriate treatment in the country of origin. ${ }^{108}$

In the meantime, a French-speaking Division of the Conseil d'État adopted a completely different approach. According to that Division, the legislature had clearly sought to confine the benefit of section 9ter to aliens who were so "seriously ill" that their removal would amount to a violation of Article 3 of the ECHR, and to ensure that the assessment in question was carried out in accordance with the ECtHR's case-law as established in the case of $N$. v. the United Kingdom. The three categories of illness concerned, where they attained a minimum level of severity, were apt to satisfy the requirements of Article 3.

The divergence in the case-law of the Conseil d'Etat was resolved on 16 October 2014 when the French-speaking Division adopted the same interpretation as the Dutch-speaking Division and proposed an "autonomous" interpretation of section 9ter, paragraph 1, in so far as that provision concerned situations of inhuman or degrading treatment on account of the lack of appropriate treatment in the receiving country. Unfortunately, these developments were not considered by national authorities in $\mathrm{Mr}$ Paposhvili's case.

As already noted, this change in the national case law occurred two years before the Grand Chamber judgment in the case of Paposhvili. The ECtHR itself noted that the case law subsequent to N. v. the United Kingdom has not provided more detailed guidance regarding the "very exceptional cases" referred to in that judgment. It therefore clarified, similarly as the Belgium Conseil d'Etat, that the "other very exceptional cases" within the meaning of the judgment in N. v. the United Kingdom which may raise an issue under Article 3 should be understood to refer to situations involving the removal of a seriously ill person in which substantial grounds have been shown for believing that he or she, although not at imminent risk of dying, would face a real risk, on account of the absence of appropriate treatment in the receiving country or the lack of access to such treatment, of being exposed to a serious, rapid

106 Section 9ter of the Aliens Act provides for the possibility of granting leave to remain on medical grounds. The first paragraph, as inserted by the Act of 15 September 2006, amended by the Act of 7 June 2009 and replaced by the Act of 29 December 2010, provided as follows at the material time: "1. Aliens resident in Belgium who provide proof of identity in accordance with paragraph 2 and who are suffering from an illness entailing a real risk to their life or physical well-being or a real risk of inhuman or degrading treatment if no appropriate treatment exists in their country of origin or previous country of residence may apply to the Minister or his or her representative for leave to remain in the Kingdom. /.../"

107 Conseil d'État of the Kingdom of Belgium, judgment no. 223.961 of $19^{\text {th }}$ June 2013.

108 Conseil d'État of the Kingdom of Belgium, judgments nos. 225.632 and 225.633 of $28^{\text {th }}$ November 2013. 
and irreversible decline in his or her state of health resulting in intense suffering or to a significant reduction in life expectancy. It pointed out that these situations correspond to a high threshold for the application of Article 3 of the ECHR in cases concerning the removal of aliens suffering from serious illness.

Since the decision in this case also summarizes the abovementioned development of the relevant case law on the national level, ${ }^{109}$ it is possible to assume that ECtHR relied to those developments in its decision. If Belgian courts had the possibility to request an advisory opinion when they were deciding on the applicant's case, they could have suggested to the ECtHR to accept their interpretation on the scope of Article 3 regarding the removal of seriously ill aliens already years before the Grand Chamber adopted its decision in the Paposhvili case. It is clear that the latter judgment raised the level of protection of seriously ill aliens who are facing a removal and we can only assume the number of such aliens who have, before this judgment, already been returned to the receiving country, in which there is no appropriate treatment.

\subsubsection{Case of G.I.E.M. S.r.l. and Others v. Italy}

The case of G.I.E.M. S.r.l. and Others v. Italy ${ }^{110}$ is of significant importance because it shows how the existence of the advisory opinion proceedings could have helped the Italian courts, which were been torn between various interpretations of the Article 7 of the ECHR and were consequently forced to adopt a decision in the matter, without having any guidance from the ECtHR. The authors analyse whether the advisory opinion proceedings could have led to faster and clearer unification of the human rights standards.

\subsubsection{Facts of the case}

The cases concerned the confiscation of land as provided for by domestic legislation in the event of unlawful site development. The applicants alleged that this confiscation had an insufficient legal basis. One of the applicants had been prosecuted for illegal site development but had not been convicted because the offence had become statute-barred. The illegally developed land had nonetheless been confiscated in its entirety. Relying on the judgment in the case of Varvara v. Italy, ${ }^{111}$ the ECtHR reiterated that Article 7 of the ECHR precluded the imposition of a criminal sanction on an individual without personal criminal liability being established and declared beforehand. Since the domestic courts had noted that all the elements of the offence of illegal site development were present, while discontinuing the proceedings on the sole ground of statute limitation, the ECtHR found that there had been a "conviction" for the purposes of Article 7 and that there had therefore been no violation of the latter in the applicant's case. As regards the applicant companies (legal entities with a legal personality distinct from that of their directors or shareholders), which had not been prosecuted as such and had not been parties to the criminal proceedings, the ECtHR

109 See Paposhvili v. Belgium [GC], no. 41738/10, 13 December 2016, paras. 101-107.

110 G.I.E.M. S.r.l. and Others v. Italy [GC], nos. 1828/06, 34163/07 and 19029/11, 28 June 2018.

111 Varvara v. Italy, no. 17475/09, 29 October 2013. 
found that they could not have been the subject of such a declaration of criminal liability, so that the confiscation of their property had been incompatible with Article 7.

\subsubsection{Would the advisory opinion proceeding have shifted the burden of solving a complex human rights standards' dilemma on the ECtHR?}

The main issue of the case was the interpretation of the provision of Construction Act, which determined that the development of a site that is carried out in the absence of a planning permission or regulation, is a punishable criminal offence and requires sentencing courts to order the confiscation of the unlawfully developed land and the illegally erected buildings. Nevertheless, Italian courts, including the Constitutional Court, considered this measure as an administrative sanction, which is authorized even when the criminal proceedings for unlawful site development do not lead to the "formal" conviction of the accused. The main question was therefore, whether such interpretation was in compliance with Article 7 of the ECHR, which precludes the imposition of a criminal sanction on an individual without personal criminal liability being established and declared beforehand.

In a separate judgment delivered in March $2015^{112}$ (six months before the Grand Chamber held an oral hearing in the case of G.I.E.M. S.r.l. and Others v. Italy), the Italian Constitutional Court suggested that, while referring to the term "conviction", the ECtHR did not have in mind the form of the ruling by a sentencing court but rather a more general finding of responsibility. The Constitutional Court further stated that the Varvara judgment cannot be unequivocally interpreted to the effect that confiscation in accordance with spatial planning provisions may only be ordered in parallel with a conviction by the courts for the offence of unlawful parceling.

The reasoning seems to have convinced the ECtHR, which delivered it decision in the case on 28 June 2018. In its judgement, the ECtHR acknowledged that even though the Varvara case states that the declaration of criminal liability is often made in a criminal-court judgment formally convicting the defendant, this should not be seen as a mandatory rule. The ECtHR therefore followed the reasoning of the Italian Constitutional Court, noting that while conviction by the domestic criminal courts may constitute one criterion for determining whether or not a measure constitutes a "penalty" within the meaning of Article 7, the absence of a conviction does not suffice to rule out the applicability of that provision. ${ }^{113}$

All in all, it is possible to conclude that if the advisory opinion proceedings had existed when national courts had been deciding on the case of G.I.E.M. S.r.l., the Italian Constitutional Court would not have to take matters into its own hands several years later, when it was faced with the same dilemma with regard to the dilemma of complex interpretation of human rights standards. Although the ECtHR later followed the reasoning of the Italian Constitutional Court, the authors believe that a prior judicial dialogue in the form of an advisory opinion could have led to the unification

112 The Constitutional Court of the Italian Republic, judgment no. 49, 14 $4^{\text {th }}$ January 2015.

113 G.I.E.M. S.r.l. and Others v. Italy [GC], nos. 1828/06, 34163/07 and 19029/11, 28 June 2018, para. 127. 
of the human rights standards in this matter already years before the ECtHR finally ruled on the matter.

\section{CONCLUSION}

With its entry into force, Protocol No. 16 to the ECHR has introduced an advisory opinion proceeding, which aims not only to reduce the ECtHR's workload, but also to foster judicial dialogue among highest national courts and the Strasbourg court. While many questions regarding the procedure itself remain open, the authors believe that this institute carries a lot of potential for the improvement of understanding and following ECHR standards already on the national level.

It has been illustrated on two ECtHR's cases against Slovenia and Belgium that a possibility for national courts to request an advisory opinion could have prevented a violation of human rights and fundamental freedoms. Furthermore, it has been shown on the ECtHR's case against Italy that due to the absence of the advisory opinion proceedings, the national courts were sometimes forced to take matters into its own hands, if certain interpretations of the ECHR standards were unclear. Since Slovenia is one of the State Parties that has ratified the Protocol, it is now only the matter of time for the national courts to make use of this institute and prove whether the predictions made in this article would come true. On the other hand, Belgium and Italy are only the Signatories of the Protocol No. 16, although the advisory opinions, issued by the ECtHR, will undoubtedly affect their interpretation of ECHR standards.

The authors believe that State Parties to the Protocol No. 16 should use the given possibility to request an advisory opinion without any hesitation for at least two reasons. Firstly, this would show that national courts can understand the complexity of ECtHR's developing case law and therefore identify the potential questions of principle with regard to the interpretation of ECHR's standards. Secondly, it would also contribute to the development and improvement of human rights' standards, which would not only effect the decision on the given case, but also contribute to the wider application of these standards in the whole Europe.

\section{Books}

1. Brkan, Maja et al. (ed), Postopki pred Sodiščem EU, Ljubljana, GV Založba, 2014.

2. Craig, Paul, de Búrca, Gráinne, EU Law: Text, cases and materials, $6^{\text {th }}$ edition, Oxford, Oxford University Press, 2015.

3. Fairhurst, John, Law of the European Union, $7^{\text {th }}$ edition, Essex, Pearson Education Limited, 2010.

4. Gerards, Janneke, Fleuren, Joseph, Implementation of the ECHR and the case-law of the European Court of Human Rights in national case-law: A comparative analysis, Antwerp, Intersentia, 2014.

5. Harris, David, O'Boyle, Michael and Warbrick, Colin, Law of the European Convention on Human Rights, Oxford, Oxford University Press, 2018.

6. Lambert-Abdelgawad, Elisabeth, The Execution of Judgments of the European Court of Human Rights, Strasbourg, Council of Europe Publishing, 2002. 
7. Popelier, Patricia, Lambrecht, Sarah, Lemmens, Koen (eds.), Criticism of the European Court of Human Rights: shifting the convention system: counter-dynamics at the national and EU level, Cambridge, Intersentia, 2016.

8. Ribičič, Ciril, Kaučič, Igor, Referendum and The European Convention on Human Rights (Entwicklungen im Europäischen Recht, Vol. 11), Regensburg, Universitätsverlag Regensburg, 2016.

9. Schabas, William A., The European Convention on Human Rights: A Commentary, Oxford, Oxford University Press, 2015.

10. Trstenjak, Verica, Brkan, Maja, Pravo EU: Ustavno, procesno in gospodarsko pravo EU, Ljubljana, GV Zalobža, 2018.

11. Varanelli, Luigi, Predhodno odločanje v evropskem pravu, Ljubljana, Uradni list Republike Slovenije, 2010.

12. Žuber, Bruna et al. (ed.), Pomen prakse in zahtev ESČP za izvedbo glavne obravnave v upravnem sporu : študija projekta. Ljubljana, Pravna fakulteta, Univerza v Ljubljani, 2018.

13. Žuber, Bruna, Ustavnosodni nadzor zakonodajnega referendum, Ljubljana, GV Založba, 2018.

1. Cameron, Iain, The Swedish Experience of the European Convention on Human Rights since Incorporation, Cambridge, The International and Comparative Law Quarterly, vol. 48, 1/1999, pp. 20-56.

2. Đorđević, Sanja, Protocol 16 to the European Convention on Human Rights and Freedoms, Niš, Law and Politics, vol. 12, 2/2014, pp. 103-111.

3. Eeckhout, Piet, Opinion 2/13 on EU Accession to the ECHR and Judicial Dialogue: Autonomy or Autarky, New York, Fordham International Law Journal, vol. 38, 4/2015, pp. 955-992.

4. Glas, Lize R.,The Boundaries to Dialogue with the European Court of Human Rights, in: Benedek, W. et al. (eds.), European Yearbook on Human Rights, Cambridge, Intersentia, 2018, pp. 287-318

5. Grabenwarter, Christoph, The European Convention on Human Rights: Inherent Constitutional Tendencies and the Role of the European Court of Human Rights, Budapest, Elite Law Journal, vol. 2, 1/2014, pp. 101-115.

6. Jahn, Jannika, Normative Guidance from Strasbourg Through Advisory Opinions: Deprivation or Relocation of the Convention's Core?, Heidelberg, Zeitschrift für ausländisches öffentliches Recht und Völkerrecht $($ ZaöRV $)=$ Heidelberg journal of international law (HJIL), vol. 74, 4/2014, pp. 821-845.

7. Jóźwicki, Władysław, Protocol 16 to the ECHR: A Convenient Tool for Judicial Dialogue and Better Domestic Implementation of the Convention?, in: E. Kużelewska, et al. (eds.), European Judicial Systems as a Challenge for Democracy, European Integration and Democracy Series, Antwerp, Intersentia, 2015, pp. 183-209.

8. Mowbray, Alastair, European Court of Human Rights: May 2013-April 2014, Hull, European Public Law, vol. 20, 4/2014, pp. 1-18.

9. Nastić, Maja, ECHR and National Constitutional Courts, Niš, Zbornik radova Pravnog fakulteta u Nišu, vol. 71, 14/2015, pp. 203-220.

10. Paprocka, Ada and Ziółkowski, Michał, Advisory opinions under Protocol No. 16 to the European Convention on Human Rights, Cambridge, European Constitutional Law Review, vol. 11, 2/2015, pp. 274-292.

11. Ribičič, Ciril, Ločena mnenja in varstvo človekovih pravic, Ljubljana, Pravna praksa, vol. 25, 41-42/2006 October 2006, pp. VIII-XII. 
12. Ribičič, Ciril, Razbremenjevanje ESČP in Ustavnega sodišča, Ljubljana, Podjetje in delo, vol. 33, 6-7/2007, pp. 993-1004.

13. Ribičič, Ciril, Ustavno sodišče - ESČP - Sodišče EU, Ljubljana, Podjetje in delo, vol. 36, 6-7/2001, pp. 1054-1061.

14. Ribičič, Ciril, Zakaj podpiram reformiranje ESČP?, Ljubljana, vol. 22, 12/; pp. I-III.

15. Rinceanu, Johanna, Judicial dialogue between the European Court of Human Rights and national supreme courts, in: C. Spinellis, et al. (eds.), Europe in Crisis: Crime, Criminal Justice, and the Way Forward. Essays in honour of Nestor Courakis. Vol. II: Essays in English, German, French, and Italian, Athens, Ant. N. Sakkoulas Publishers L.P., 2017, pp. 1029-1041.

16. Sabato, Raffaele, Judicial dialogue: The experience of Italy, in: Müller, A. (ed.), Judicial dialogue and human rights, Cambridge, Cambridge University Press, 2017, pp. 267-284.

17. Spaventa, Eleanor, A very fearful Court? The protection of fundamental rights in the European Union after Opinion 2/13, Maastricht, Maastricht journal of European and comparative law, vol. 22, 1/2015, pp. 35-56.

18. Zoethout, Carla M., The European Court of Human Rights and Transnational Judicial Dialogue, Vienna, Vienna Journal on International Constitutional Law, vol. 9, 3/2015, pp. 398-416.

\section{Internet sources}

1. Boštele, Mojca, Vrhovno sodišče: Argumentacija ESČP je neprepričljiva, <https://www. delo.si/novice/slovenija/vrhovno-sodisce-argumentacija-escp-je-neprepricljiva-106336. html>, 25th of October 2018, 6th of November 2018.

2. Council of Europe, France ratifies Protocol No. 16 to the European Convention on Human Rights, triggering its entry into force, <https://www.coe.int/en/web/tbilisi/-/ france-ratifies-protocol-no-16-to-the-european-convention-on-human-rights-triggeringits-entry-into-force> 12th of April 2018, 8th of December 2018.

3. Vrhovno sodišče po plazu kritik umaknilo sporno sporočilo v zadevi Pro Plus, $<\mathrm{http} / /$ www.rtvslo.si/slovenija/vrhovno-sodisce-po-plazu-kritik-umaknilo-sporno-sporocilo-vzadevi-pro-plus/470349>, 29th of October 2018, 6th of November 2018.

\section{Legal acts}

Slovenia, the Republic

1. Administrative Dispute Act, Official Gazette no. 105/06, 107/09, 62/10, 98/11, 109/12 and 10/17.

2. Constitution of the Republic of Slovenia, Official Gazette no. 33/91-I, 42/97, 66/00, 24/03, 69/04, 69/04, 69/04, 68/06, 47/13, and 75/16.

3. Constitutional Court Act, Official Gazette no. 109/12 (official consolidated text).

4. Courts Act, Official Gazette, no. 94/07, 45/08, 96/09, 86/10, 33/11, 75/12, 63/13, 17/15, $23 / 17$ and $22 / 18$.

5. Prevention of Restriction of Competition Act, Official Gazette no. 36/08, 40/09, 26/11, $87 / 11,57 / 12,39 / 13,63 / 13,33 / 14,76 / 15$ and $23 / 17$.

\section{International contracts}

1. Act Ratifying European Convention for the Protection of Human Rights and Fundamental Freedoms, Official Gazette International Contracts, 7-41/1994.

2. Act Ratifying Protocol No. 16 to the Convention for the Protection of Human Rights and Fundamental Freedoms, Official Gazette International Contracts, no. 1/15.

3. Consolidated version of the Treaty on the Functioning of the European Union. OJ C 326, 26 October 2012, pp. 47-390. 
Court practice

Practice of Belgian national courts

1. Conseil d'État of the Kingdom of Belgium, judgment no. 223.961 of 19th June 2013.

2. Conseil d'État of the Kingdom of Belgium, judgments nos. 225.632 and 225.633 of 28th November 2013.

Practice of the CJEU

1. Case C-283/81 CILFIT v. Ministry of Health [1982] ECR 3415.

Practice of the ECtHR

1. Bendenoun v. France, no. 12547/86, 24 February 1994.

2. Cyprus v. Turkey [GC], no. 25781/94, 10 May 2001.

3. D. v. the United Kingdom, no. 30240/96, 2 May 1997.

4. Engel and Others v. the Netherlands, nos. 5100/71, 5101/71, 5102/71, 5354/72 and 5370/72, 8 June 1976.

5. G.I.E.M. S.r.l. and Others v. Italy [GC], nos. 1828/06, 34163/07 and 19029/11, 28 June 2018.

6. Hirst v. the United Kingdom (no. 2) [GC], no. 74025/01, 6 October 2005.

7. Jussila v. Finland [GC], no. 73053/01, 23 November 2006.

8. Lundevall v. Sweden, no. 38629/97, 12 November 2002.

9. Lutz v. Germany, no. 9912/82, 25 August 1987.

10. Miller v. Sweden, no. 55853/00, 8 February 2005.

11. Mladina d.d. Ljubljana v. Slovenia, no. 20981/10, 17 April 2014.

12. Motion Pictures Guarantors Ltd v. Serbia, no. 28353/06, 8 June 2010.

13. N. v. the United Kingdom [GC], no. 26565/05, 27 May 2008.

14. Paposhvili v. Belgium [GC], no. 41738/10, 13 December 2016,

15. Produkcija Plus storitveno podjetje d.o.o. v. Slovenia, no. 47072/15, 23 October 2018.

16. Salomonsson v. Sweden, no. 38978/97, 12 November 2002.

17. Sramek v. Austria, no. 8790/79, 22 October 1984.

18. Suuripää v. Finland, no. 43151/02, 12 January 2010.

19. Swedish Engine Drivers' Union v. Sweden, no. 5614/72, 6 February 1976.

20. Varvara v. Italy, no. 17475/09, 29 October 2013.

Practice of Italian national courts

1. The Constitutional Court of the Italian Republic, judgment no. 49, 14th January 2015.

Practice of Slovene national courts

1. Constitutional Court of the Republic of Slovenia, U-I-238/12 from 23rd January 2014.

2. Constitutional Court of the Republic of Slovenia, U-II-1/15 from 28th September 2015.

Practice of Swedish national courts

1. The Supreme Court of Sweden, NJA 2010 s. 168 I-II from 31th March 2010.

2. The Supreme Court of Sweden, NJA 2013 s. 502 from 11th June 2013

3. The Supreme Court of Sweden, NJA 2005 s. 805 from 29th November 2005. 


\section{Bruna Žuber* \\ Špela Lovšin**}

Sažetak

\section{SUDSKI DIJALOG U SVJETLU PROTOKOLA BROJ 16 UZ EUROPSKU KONVENCIJU ZA ZAŠTITU LJUDSKIH PRAVA}

Autorice raspravljaju o pravnoj prirodi Protokola broj 16 uz Europsku konvenciju za zaštitu ljudskih prava (EKLJP), koji je stupio na snagu 1. kolovoza 2018. Sa svrhom poboljšanja sudskog dijaloga između Europskog suda za ljudska prava (ESLJP) i najviših nacionalnih sudova, je Protokol broj 16, na razini ESLJP, uveo postupak davanja savjetodavnih mišljenja. Članak uključuje detaljnu analizu utjecaja postupka za davanje savjetodavnih mišljenja na sudski dijalog, koja je dodatno podržana pregledom slučaja pred ESLJP-om protiv Slovenije, Belgije i Italije, koji pokazuju, kako bi mogućnost podnošenja zahtjeva za savjetodavno mišljenje mogla spriječiti utvrđivanje povrede ljudskih prava u Strasbourgu i povećati učinkovitost standarda ljudskih prava. Autorice vjeruju da je Protokol broj 16 donio ogroman potencijal za poboljšanje sudskog dijaloga, što može dovesti i do boljeg razumijevanja standarda ECHR-a, kako ih tumači EKLJP, čime se sprječava povreda ljudskih prava već na nacionalnoj razini.

Ključne riječi: sudski dijalog; Protokol broj 16 uz Europsku konvenciju za zaštitu ljudskih prava; savjetodavno mišljenje; Europski sud za ljudska prava.

Zusammenfassung

\section{JUSTIZIELLER DIALOG IM LICHTE DES ZUSATZPROTOKOLLS NR. 16 DER EUROPÄISCHEN KONVENTION ZUM SCHUTZ DER MENSCHENRECHTE UND GRUNDFREIHEITEN}

Im Beitrag wird die Rechtsnatur des Zusatzprotokolls Nr. 16 der Europäischen Konvention zum Schutz der Menschenrechte und Grundfreiheiten besprochen,

* dr. sc. Bruna Žuber, asistentica na Pravnom fakultetu Sveučilišta u Ljubljani i viša sudska savjetnica na Vrhovnom sudu Republike Slovenije, bruna.zuber@pf.uni-lj.si.

** Špela Lovšin, diplomirana pravnica i polaznica magistarskog studija, Pravni fakultet Sveučilišta u Ljubljani, spelalovsin@gmail.com. 
welcher am 1. August 2018 in Kraft trat. Mit dem Ziel der Verbesserung des justiziellen Dialogs zwischen dem Europäischen Gerichtshofs für Menschenrechte (EGMR) und den höchsten nationalen Gerichten hat der Zusatzprotokoll Nr. 16 ermöglicht, dass sich die letztinstanzlichen nationalen Gerichte mit Fragen zur Auslegung der EMRK für ein Gutachten an den EGMR wenden können. Dieser Beitrag beinhaltet eine erschöpfende Analyse des Einflusses solchen Gutachtenverfahrens auf justiziellen Dialog. Ebenfalls stellt der Beitrag zwei Fälle gegen Slowenien vor dem EGMR dar, die zeigen, dass die Möglichkeit der letztinstanzlichen Gerichte, sich an den EGMR für ein Gutachten anwenden zu können, die Feststellung einer Verletzung von Menschenrechten in Strasbourg verhindern könnten. Im Beitrag wird die Ansicht vertreten, dass der Zusatzprotokoll Nr. 16 sehr stark der Verbesserung des justiziellen Dialogs beigetragen hat, was gleichzeitig auch zum besseren Verständnis der vonseiten des EGMR ausgelegten Standards der EMRK beibringt. Dadurch kann man die Verletzung der Menschenrechte schon auf nationaler Ebene verhindern.

Schlüsselwörter: justizieller Dialog; Zusatzprotokoll Nr. 16 der Europäischen Konvention zum Schutz der Menschenrechte und Grundfreiheiten; Gutachten; Europäischer Gerichtshof für Menschenrechte.

Riassunto

\section{IL DIALOGO GIUDIZIALE ALLA LUCE DEL PROTOCOLLO NUM. 16 ALLA CONVENZIONE EUROPEA PER LA SALVAGUARDIA DEI DIRITTI DELL'UOMO E DELLE LIBERTÀ FONDAMENTALI}

Le autrici dibattono della natura giuridica del Protocollo num. 16 alla Convenzione europea per la salvaguardia dei diritti dell'uomo e delle libertà fondamentali (CEDU), entrato in vigore l'1 agosto 2018 con l'intento di migliorare il dialogo giudiziale tra la Corte dei diritti dell'uomo e le massime istanze giudiziali nazionali, introducendo sul piano della CEDU la procedura di rilascio di pareri consultivi. Lo scritto prevede un'analisi dettagliata dell'influenza della procedura di rilascio pareri consultivi sul dialogo giudiziale, come anche l'analisi di due casi contro la Slovenia dinnanzi alla Corte dei diritti dell'uomo, i quali dimostrano come la possibilità di richiedere un parere consultivo potrebbe evitare la condanna per la violazione di diritti umani a Strasburgo. Le autrici credono che il Protocollo num. 16 abbia portato un enorme potenziale per il miglioramento del dialogo giudiziale, il che potrebbe condurre altresì ad una maggiore consapevolezza degli standard della Corte dei diritti dell'uomo, come intesi dalla CEDU, il che porta alla diminuzione delle violazione dei diritti umani già sul piano nazionale. 
Parole chiave: dialogo giudiziale; Protocollo num. 16 della Convenzione europea per la salvaguardia dei diritti dell'uomo e delle libertà fondamentali; pareri consultivi; Corte europea dei diritti dell'uomo. 